\title{
DANIO RERIO (ACTINOPTERYGII: CYPRINIFORMES: CYPRINIDAE): A NEW RECORD FROM ANDAMAN ISLANDS, INDIA
}

\author{
Jayasimhan PRAVEENRAJ, Rajendran KIRUBA-SANKAR, Sibnarayan DAM ROY, \\ Kumar LOHITH, Kumar SHAILESH, Jesudhas RAYMOND JANI ANGEL, \\ and Ramarao VENKATESH THAKUR
}

\author{
Indian Council of Agricultural Research, Central Island Agricultural Research Institute, Port Blair, Andaman and \\ Nicobar Islands, India
}

\begin{abstract}
Praveenraj J., Kiruba-Sankar R., Dam Roy S., Lohith K., Shailesh K., Raymond Jani Angel J., Venkatesh Thakur R. 2017. Danio rerio (Actinopterygii: Cypriniformes: Cyprinidae): Anew record from Andaman Islands, India. Acta Ichthyol. Piscat. 47 (4): 391-396.
\end{abstract}

\begin{abstract}
Danio rerio (Hamilton, 1822) is reported herewith for the first time from Andaman group of islands, which is a new addition to the freshwater fish fauna and also a significant insular record other than its known distribution range. The morphological description of $D$. rerio collected from North and Middle Andaman Island and the mainland, India topotypes are provided along with the molecular genetic comparison.
\end{abstract}

Keywords: zebrafish, archipelago, insular, freshwater fish, record

The Andaman and Nicobar Islands in the Bay of Bengal, stretching between $6^{\circ} 45^{\prime}-13^{\circ} 45^{\prime} \mathrm{N}$ and $92^{\circ} 10^{\prime}-94^{\circ} 15^{\prime} \mathrm{E}$, consist of 572 islands. These islands are characterized by a rich diversity of flora and fauna with a high level of endemism (Rao et al. 2013). There has been only few records of freshwater fishes in the faunistic studies concerning those islands (Day 1870, 1876, 1878, Annandale and Hora 1925, Mukerji 1935, Herre 1939, 1940, 1941, Koumans 1940, Starmühlner 1976, Rao et. al 2000, Palavai and Davidar 2009, Devi 2010, Rajan and Sreeraj 2013, Rajan et al. 2013, Rajan and Sreeraj 2014a, 2014b, 2014c, Arun Kumar et al. 2016). An attempt to document the freshwater fishes was initiated by CIARI (Central Island Agricultural Research Institute), Port Blair during 2015, resulted in recording the occurrence of Danio rerio (Hamilton, 1822) from Middle and North Andaman. This paper describes this finding as a new record to the Andaman Islands.

Four specimens of Danio rerio, three from the Kalpong River, one from a marsh near Kalipur beach, Diglipur, North Andaman and six specimens from Rangat, Middle Andaman were collected (Fig. 1). Specimens were preserved in $90 \%$ ethanol. All were compared with the topotypes collected from Kolkata, India by Soutrik Ghosh. Counts and measurements are based on Hubbs and Lagler (1964) and expressed in the percentage of standard length (SL) and head length (HL). Numbers in parenthesis after a count denotes the frequency of that count. DNA was extracted from one $D$. rerio specimen from North and two specimens from Middle Andaman using the standard protocol of Bruce et al. (1993). Partial mitochondrial gene 16S ribosomal RNA (16S) (Palumbi et al. 2002) was sequenced in ABI 3500 DNA analyser. The edited and trimmed sequences of $D$. rerio were submitted to the NCBI database (KY945239, KY945240, and KY242364). The homology of the generated sequence was analysed using the Basic Local Alignment Search Tool (BLAST) program in the National Centre for Biotechnology Information. Additional sequences of Danio spp. (AY788011, AY054970, AB741876, KT835295, KT624625-26, AY707452, and AY707455) were downloaded from the NCBI database to infer phylogenetic tree. All the specimens examined were deposited in the museum of the National Bureau of Fish Genetic Resources (NBFGR), Cochin (CH), Kerala, India and in the freshwater fish collection of the Central Island Agricultural Research Institute, Port Blair (CIARI/FF).

\section{Family CYPRINIDAE \\ Danio Hamilton, 1822 \\ Danio rerio (Hamilton, 1822)}

Materials examined. Danio rerio (Figs.2A, 2B): NBFGRCH-1180, 3, 19.23-22.24 mm SL, Kalpong River, Diglipur, 


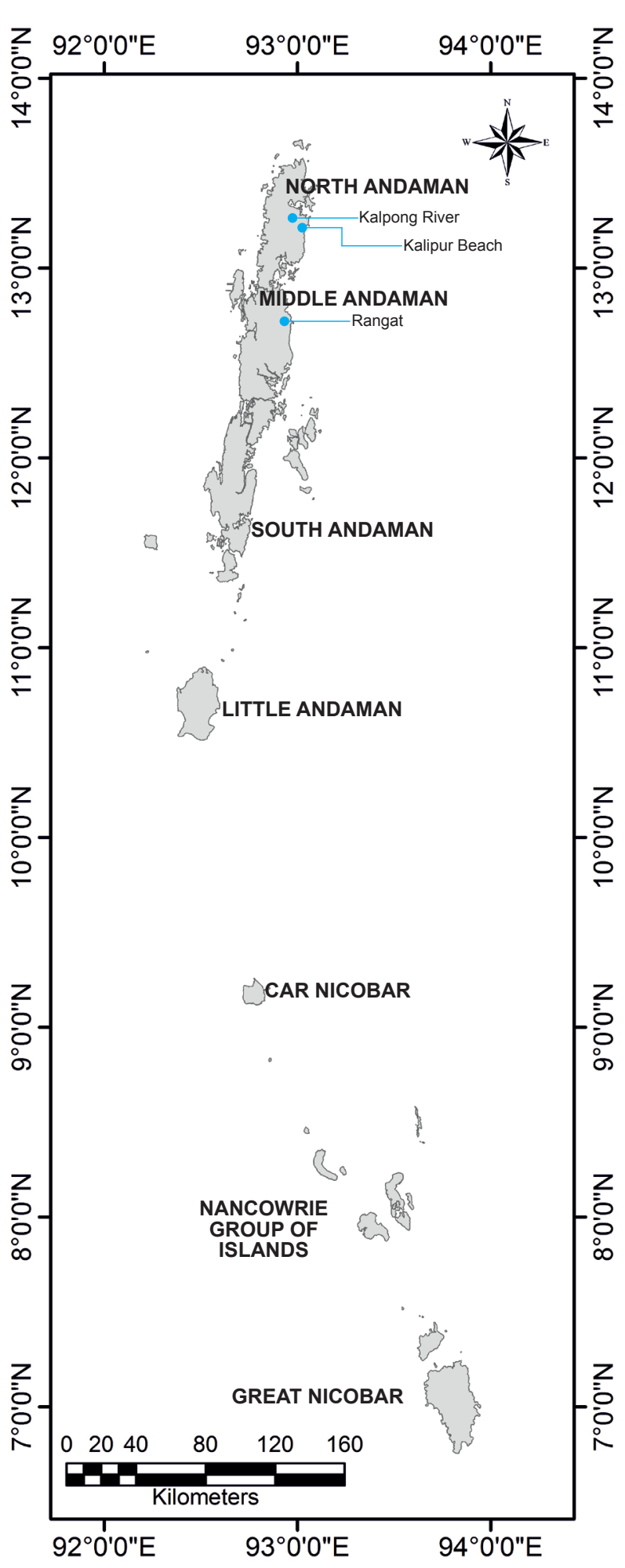

Fig. 1. Map of the Andaman and Nicobar Islands showing the sampling sites

North Andaman, India $\left(13^{\circ} 14.40^{\prime} \mathrm{N}, 92^{\circ} 58.39^{\prime} \mathrm{E}\right), \quad 1$ specimen, 29.96 mm SL, Kalipur Marsh, Diglipur, North Andaman, Praveenraj and Raymond Jani Angel, 26 Oct 2015 NBFGR-CH-1180, 1 specimen, 29.96 mm SL, Kalipur Marsh, near Kalipur beach, Diglipur, North Andaman, India, $\left(13^{\circ} 13.52^{\prime} \mathrm{N}, 93^{\circ} 02.67^{\prime} \mathrm{E}\right)$, Praveenraj and Raymond Jani Angel, 26 Oct 2015. CIARI/FF-01, 6 specimens,
23.7-35.5 mm SL, Rangat, Middle Andaman, India $\left(12^{\circ} 43.22^{\prime} \mathrm{N}, 92^{\circ} 53.11^{\prime} \mathrm{E}\right)$, Sailesh Kumar, 19 Apr 2016.

Comparative material. Danio rerio (Fig. 2C): NBFGRCH-1179, 6 specimens, 18.7-21.1 mm SL, Alipurduar, Kolkata, India, Soutrik Ghosh, 15 Nov 2016.

Description. Body slender, laterally compressed, ventral portion more arched than dorsal. Head small and oval with small mouth, obliquely directed upward; lower jaw longer than upper jaw. Eyes moderate with circular pupil. Two pairs of barbels present, rostral pair longer than eye diameter and maxillary pair extending to pectoral fin base. Dorsal fin oval; anal fin marginally truncate; caudal fin forked and its anterior and posterior edge oval; pectoral fin sharp at anterior region; pelvic fin small; lateral line incomplete. Coloration: body pale olivaceous with four metallic-blue lines originating from head to caudal fin base and three golden lines running parallelly between blue lines. Caudal and anal fin barred with four blue stripes and interrupted by yellow stripes running parallel. Dorsal fin yellowish, bordered with faint blue to white stripe. Eyes silvery with melanophores scattered over it anteriorly. Comparative morphometric and meristic data of $D$. rerio specimens from the Middle and North Andaman and the mainland India, (topotypes) are provided in Table 1.

Molecular characterization. All the Danio rerio sequences generated under the accession number KY945239, KY945240 (Middle Andaman) and KY242364 (North Andaman) matched 99\%-100\% identity with existing 16S rRNA sequences of D. rerio (GenBank: KT624624, KT624625, KT624626). Maximum Likelihood method based on the Kimura 2-parameter model (Kimura 1980), was conducted using MEGA (Molecular Evolutionary Genetics Analysis) version 7 (Kumar et al. 2016), to provide a phylogenetic tree representing patterning of divergences (Fig. 3)

Distribution. Danio rerio has a wide distribution from northern Myanmar, Nepal, Bangladesh, Ganges and Brahmaputra rivers basins in north-eastern India and southern India (Barman 1991, Talwar and Jhingran 1991, Spence et al. 2006)

Remarks. Danio rerio was described as "Cyprinus rerio" from the Kosi River, a tributary of the Ganges River in Bengal, India, and was placed under the genus "Danio" as a division of "Cyprinus" (Hamilton 1822). After the proposal of the genus "Brachydanio" by Weber and de Beaufort (1916), the smaller species with seven branched dorsal rays and incomplete or absent lateral line were placed under Brachydanio (including D. rerio) and the larger bodied forms under Danio (see Chu 1981). Chu (1981) synonymised Brachydanio with Danio because of overlapping characters. Subsequently, Barman (1991) lumped all 'Danio, Brachydanio and Devario' in a single genus "Danio". After a thorough phylogenetic and morphological analysis by Fang (2003), the genus Danio and Devario were found to be distinct, and the genus Brachydanio was also synonymised with Danio, and the name $D$. rerio came into usage.

The occurrence of $D$. rerio from the Andaman Islands is an interesting geographic record from the insular 


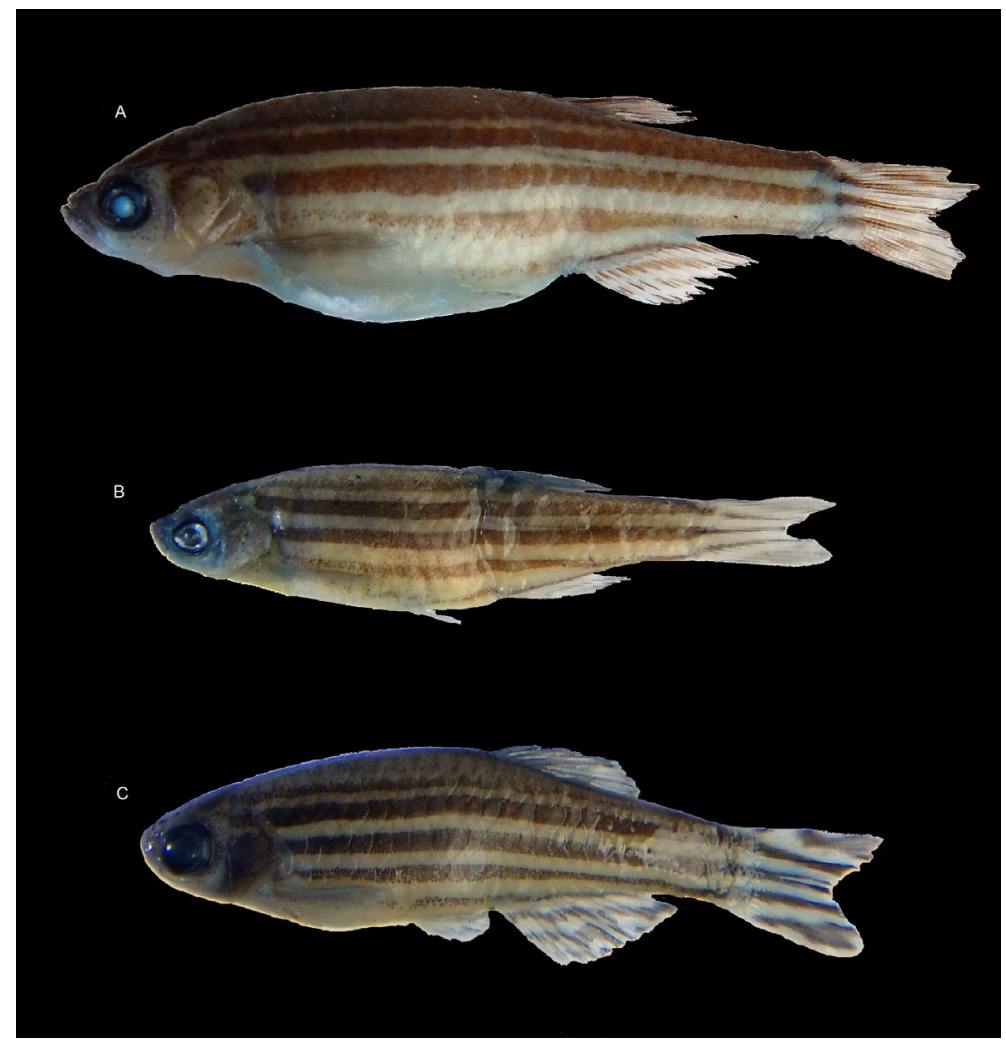

Fig. 2. Danio rerio CIARI/FF-01, $33.78 \mathrm{~mm} \mathrm{SL}$, gravid female, Rangat, Middle Andaman (preserved) (A); NBFGRCH-1180, 22.4 mm SL, Kalpong River, Diglipur, North Andaman (preserved) (B); NBFGR-CH-1179, 24.7 mm SL, Alipurduar, Kolkata (freshly preserved) (C); photo credit: J. Praveenraj

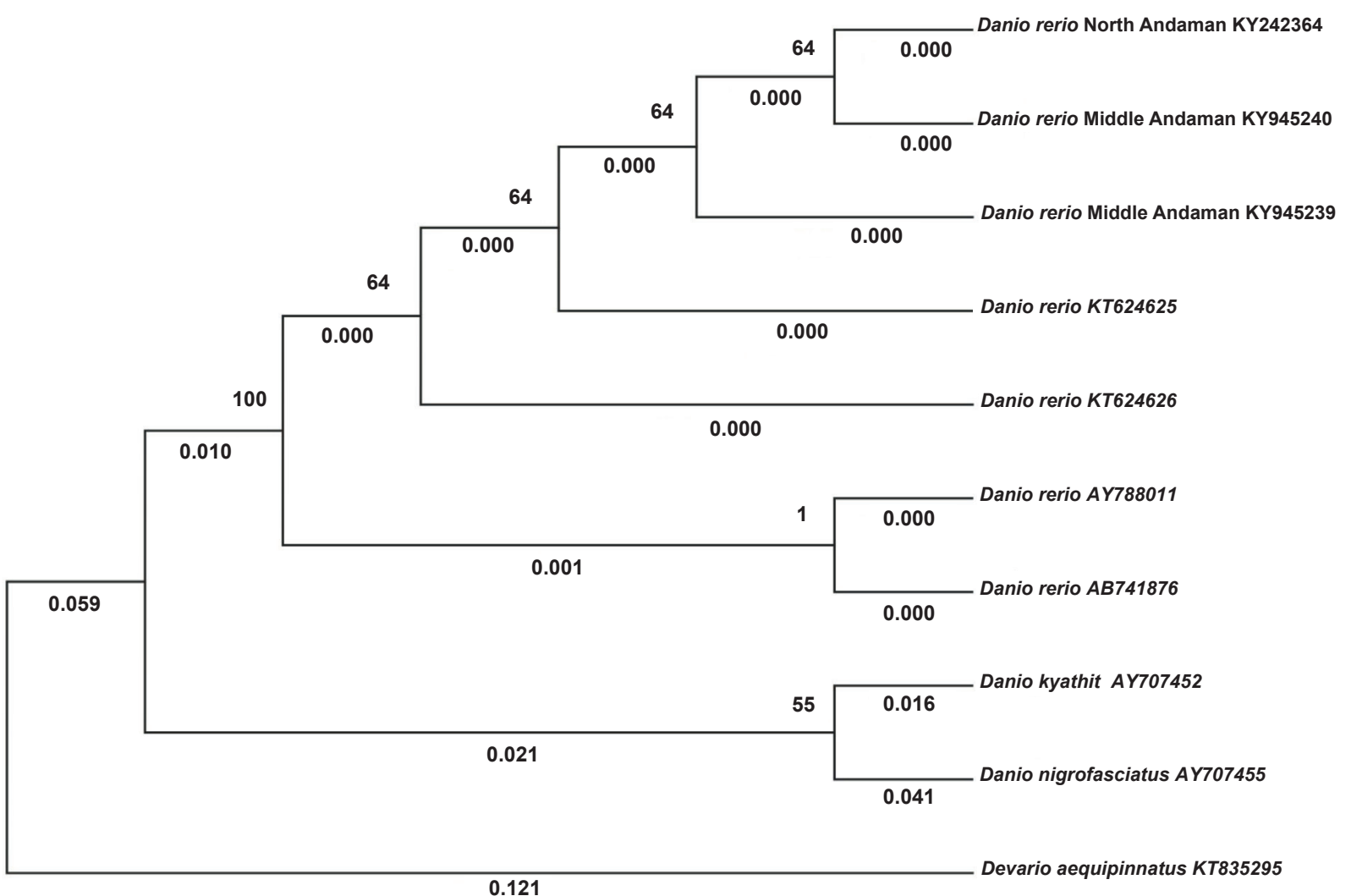

Fig. 3. Maximum likelihood phylogenetic tree of Danio spp. inferred from DNA sequences of Ribosomal 16SRNA gene; Devario aequipinnatus (McClelland, 1839) is used as out-group 


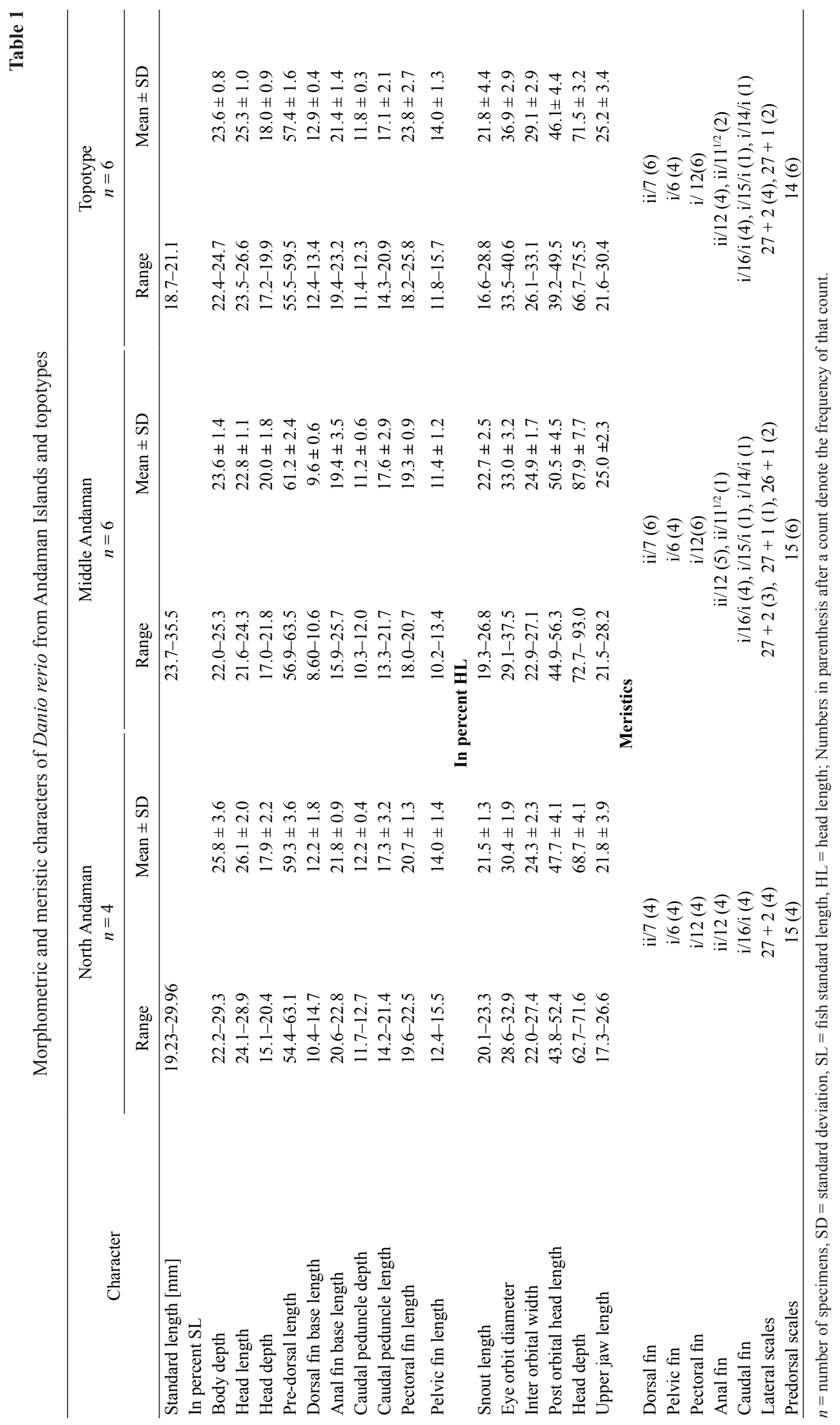


freshwaters. Recently the distributional record of $D$. rerio from peninsular India has been reported (Whiteley et al. 2011), and the natural history of various populations from peninsular India, northern part, eastern and north-eastern parts of India were studied (Arunachalam et al. 2013). Hence the distributional records are from the Cauvery River basin, the Krishna River basin, and the Sharavati River basin from peninsular India, tributaries of the Ganges River basin, the Mahanadi River basin and tributaries of the Brahmaputra River basin. In the presently reported study, no significant variations in the meristic and morphometric characters between $D$. rerio specimens from the Andaman Islands, the topotypes, and the data from Day $(1876,1878)$ and Barman (1991) were observed. Overall, the morphological and molecular data confirmed the taxon identity. However, the new distributional record of $D$. rerio from the Andaman Islands is surprisingly far from its supposed native range, which suggests an accidental introduction through freshwater aquaculture. It is reported that alien fish introductions at the Andaman and Nicobar Islands are believed to be done during the British rule (Rajan and Sreeraj 2014c). History on carp introduction in the Andaman Islands is known from the records of Annandale and Hora (1925) and Mukerji (1935). Five species of air-breathing fishes are well established in the native waters; three species of Gangetic carps, one species of barb, and four species of exotic carps are being cultured in ponds (Sen 1975, Mohanraj et al. 1999, Palavai and Davidar 2009, Rajan and Sreeraj 2013, Rajan and Sreeraj 2014c). However, there are no reports of introduced carps from native waters. North and Middle Andaman islands have a numerous population of local Bengali settlers, involved in aquaculture of Gangetic and exotic Chinese carps. To a large extent, carp spawns are bought from mainland Kolkata and there is an ample chance of weed-fishes introduction, coming along with it as a contaminant. Hence, the presently reported findings of $D$. rerio from the Andaman Islands may probably be a result of a deliberate release or escape from fish farms. Danio rerio is generally omnivorous, and their natural diet consists of zooplankton, insect, and phytoplankton, filamentous algae, invertebrate eggs, arachnids and detritus (McClure et al. 2006, Spence et al. 2007). The establishment of $D$. rerio population in the naturals waters of Middle and North Andaman may pose a serious ecological threat in the form of competition for food and space with the native fishes. Comprehensive studies might impart more knowledge on their behaviour and feeding ecology in the insular freshwaters of Andaman Islands.

\section{ACKNOWLEDGEMENTS}

We thank the externally funded project on 'consortia research platform on agrobiodiversity', for the grants to carry out the research. We also thank Titus Emmanuel and Bitopan for their assistance in the field. We thank Soutrik We thank Soutrik Gosh of Kolkata, Beta Mahatvaraj, Shankar Balasubramanian and Elan Chezhiyan of Chennai for facilitating the provision the live topotype specimens. The first author acknowledges, M.P. Goutham Bharati for the preparation of maps

\section{REFERENCES}

Annandale N., Hora S.L. 1925. The freshwater fish from the Andaman Islands. Records of the Indian Museum 27 (2): 33-41.

Arun Kumar M., Venu S., Padmavati G. 2016. Habitat ecology and ichthyofaunal diversity of two creeks and their associated streams from Port Blair, South Andaman Islands. International Journal of Ecology 2016: article 1649368 .

DOI: $10.1155 / 2016 / 1649368$

Arunachalam M., Raja M., Vijayakumar C., Malaiammal P., Mayden R.L. 2013. Natural history of zebrafish (Danio rerio) in India. Zebrafish 10 (1): $1-14$.

DOI: 10.1089/zeb.2012.0803

Barman R.P. 1991. A taxonomic revision of the IndoBurmese species of Danio Hamilton Buchanan (Pisces: Cyprinidae). Record of the Zoological Survey of India Occasional Papers No. 137: 1-91.

Bruce L.D., Trumper B.B., Lightner D.V. 1993. Methods for viral isolation and DNA extraction for a penaeid shrimp baculovirus. Journal of Virological Methods 34 (3): 245-254. DOI: 10.1016/0166-0934(91)90104-8

Chu X. L. 1981. A preliminary revision of fishes of the genus Danio from China. Zoological Research 2 (2): $145-156$.

Day F. 1870. On the fishes of the Andaman Islands. Proceedings of the Zoological Society of London 1870: 677-705.

Day F. 1876. The fishes of India; being a natural history of the fishes known to inhabit the seas and fresh waters of India, Burma, and Ceylon. Volume I. Bernard Quaritch, London, England.

Day F. 1878. The fishes of India; being a natural history of the fishes known to inhabit the seas and fresh waters of India, Burma, and Ceylon. Volume II. Bernard Quaritch, London, England.

Devi K.R. 2010. [28] Freshwater fishes of Andaman Islands. Pp. 329-339. In: Ramakrishna, Raghunathan C., Sivaperuman C. (eds.) Recent trends in biodiversity of Andaman and Nicobar Islands. Zoological Survey of India, Kolkata, India.

Hamilton (Buchanan) F. 1822. An account of the fishes found in the river Ganges and its branches. George Ramsay and Co., Edinburgh, Scotland. DOI: $10.5962 /$ bhl.title. 6897

Herre A.W.C.T. 1939. On a collection of littoral and freshwater fishes from the Andaman Islands. Records of the Indian Museum 41 (4): 327-372.

Herre A.W.C.T. 1940. On a collection of littoral and freshwater fishes from the Andaman Islands: Supplement. Records of the Indian Museum 41: 1-8.

Herre A.W.C.T. 1941. A list of the fishes known from the Andaman Islands. Memoirs of the Indian Museum 13 (3): 331-403.

Hubbs C.L., Lagler K.F. 1964. Fishes of the Great Lakes region. The University of Michigan Press, Ann Arbor, MI, USA. 
Koumans F.P. 1940. On the collection of gobioid fishes from Andamans. Records of the Indian Museum 42: $15-18$.

Kumar S., Stecher G., Tamura K. 2016. MEGA7: Molecular Evolutionary Genetics Analysis version 7.0 for bigger datasets. Molecular Biology and Evolution 33 (7): $1870-1874$.

DOI: $10.1093 / \mathrm{molbev} / \mathrm{msw} 054$

Kimura M. 1980. A simple method for estimating evolutionary rate of base substitutions through comparative studies of nucleotide sequences. Journal of Molecular Evolution 16 (2): 111-120.

DOI: $10.1007 / \mathrm{BF} 01731581$

McClure M.M., McIntyre P.B., McCune A.R. 2006. Notes on the natural diet and habitat of eight danionin fishes, including the zebrafish Danio rerio. Journal of Fish Biology 69 (2): 553-570. DOI: 10.1111/j.1095-8649.2006.01125.x

Mohanraj P., Veenakumari K., Bandyopadhyay A.K. 1999. Perilous aliens; plant and animal introduction to the Andaman and Nicobar Islands. Society for Andaman and Nicobar Ecology, Port Blair, Andaman and Nicobar Islands, India.

Mukerji D.D. 1935. Notes on some rare and interesting fishes from the Andaman Islands, with descriptions of two new freshwater gobies. Records of the Indian Museum 37 (3): 259-277.

Palavai V., Davidar P. 2009. A survey of freshwater fishes of Andaman Islands. Journal of the Bombay Natural History Society 106 (1): 11-14.

Palumbi S., Martin A., Romano S., McMillan W.O., Stice L., Grabowski G. 2002. The simple fool's guide to PCR. Version 2.0. Department of Zoology and Kewalo Marine Laboratory, University of Hawaii, Honolulu, HI, USA.

Rajan P.T., Sreeraj C.R. 2013. Diversity, distribution and conservation of freshwater fishes in Mount Harriet National Park, Andaman and Nicobar Islands. Records of the Zoological Survey of India 113 (4): 35-55.

Rajan P.T., Sreeraj C.R. 2014a. New record of two species of Belobranchus (Teleostei: Gobioidei: Eleotridae) from Andaman Islands. Records of the Zoological Survey of India 114 (1): 185-188.

Rajan P.T., Sreeraj C.R. 2014b. Seven new records of fishes from Andaman Islands. Records of the Zoological Survey of India 114 (1): 111-117.
Rajan P.T., Sreeraj C.R. 2014c. Invasive freshwater fishes and its threats to the biological diversity in Andaman and Nicobar Islands. Journal of the Andaman Science Association 19 (1): 88-98.

Rajan P.T., Sreeraj C.R., Immanuel T. 2013. Fishes of Andaman and Nicobar Islands: A checklist. Journal of the Andaman Science Association 18 (1): 47-87.

Rao D.V., Chandra K., Devi K. 2013. Endemic animals of Andaman and Nicobar Islands; Bay of Bengal. Zoological survey of India (E-Publication) 182. http:// faunaofindia.nic.in/PDFVolumes/spb/057/index.pdf

Rao D.V., Devi K., Rajan P.T. 2000. An account of Ichthyofauna of Andaman and Nicobar Islands, Bay of Bengal. Records of Zoological Survey of India, Occasional Paper No. 178.

Spence R., Fatema M.K., Ellis S., Ahmed Z.F., Smith C. 2007. Diet, growth and recruitment of wild zebrafish in Bangladesh. Journal of Fish Biology 71 (1): 304-309. DOI: $10.1111 /$ j.1095-8649.2007.01492.x

Spence R., Runa K.F., Reichard M., Huq K.A., Wahab M.A., Ahmed Z.F., Smith C. 2006. The distribution and habitat preferences of the zebrafish in Bangladesh. Journal of Fish Biology 69 (5): 1435-1448. DOI: $10.1111 /$ j.1095-8649.2006.01206.x

Starmühlner F. 1978. Results of the Austrian-Indian Hydrobiological Mission 1976 to the Andaman-Islands: Part VII: List of Fishes collected in running Waters of the Andaman-Islands. Annalen des Naturhistorischen Museums in Wien. Serie B für Botanik und Zoologie 86: $219-224$.

Talwar P.K., Jhingran A.G. 1991. Inland fishes of India and adjacent countries. Volume 2. A.A. Balkema, Rotterdam, the Netherlands.

Weber M., de Beaufort L.F. 1916. The fishes of the Indo-Australian archipelago. III. Ostariophysi: II Cyprinoidea, Apodes, Synbranchi. E.J. Brill Leiden, the Netherlands.

Whiteley A.R., Bhat A., Martins E.P., Mayden R.L., Arunachalam M., Uusi-Heikkila S., Ahmed A.T.A., Shrestha J., Clark M., Stemple D., Bernatchez L. 2011. Population genomics of wild and laboratory zebrafish (Danio rerio). Molecular Ecology 20 (20): 4259-4276.

DOI: 10.1111/j.1365-294X.2011.05272.x

Received: 3 May 2017

Accepted: 21 August 2017

Published electronically: 31 December 2017 